\title{
John Rastell's London Stage: Reconstructing Repertory and Collaborative Practice
}

Maura Giles-Watson

Early Theatre 16.2 (2013), 171-184

DOI: http://dx.doi.org/10.12745/et.16.2.10

\begin{abstract}
The study of repertory has greatly illuminated practices among playwrights and playing companies in the later sixteenth century. The repertory approach has yet to be applied to early and mid-Tudor drama, although this method holds out the promise of recovering the collaborative practices connected with John Rastell's stage - the first public stage in London. This article urges scholars active in repertory studies to take a fresh look at Henrician drama and theatrical practices, and employs Heywood and Rastell's play Gentylnes and Nobylyte as a case study in the forces that shaped repertory in this earlier period.
\end{abstract}

In the past twenty-five years the emergence and growth of repertory studies - greatly enabled by the discoveries of the Records of Early English Drama project - has enriched our understanding of the interrelations among playing, playwriting, and performance practices on Elizabethan and Stuart stages. ${ }^{1}$ As a method of inquiry, the study of repertory employs 'literary-critical, bibliographical, and theatrical' approaches ${ }^{2}$ that focus not only on plays as texts, but also on plays as material artifacts that raise and respond to questions regarding a host of theatrical mysteries. Repertory methods have yet to be applied to early and mid-Tudor drama even though this perspective holds out the possibility of illuminating vexed issues concerning patronage, performance space, performance practice, spectatorship, and authorship particularly collaborative authorship. For works from this period, authorship is frequently difficult to determine, but it is useful to analyze plays with contested attribution for the clues they may hold to the practices of playwrights and producers and the collaborative networks within which they operated. ${ }^{3}$ This essay examines the playwriting and producing activities of John Rastell and his network in light of such repertorial considerations.

Although London theatrical practices changed radically with the development of the later sixteenth-century professional playing companies and commercial theatres, the roots of later stage practices are traceable to the activities of earlier playwrights, players, and patrons. Indeed, the development and

Maura Giles-Watson (mgileswatson@sandiego.edu) is assistant professor of English at the University of San Diego. 
performance of plays in repertory appear to have been two such practices among many that were transferred from popular and household performance to the commercial stage. Henry VII established the King's Players, a royal household troupe of interluders, in 1494 . Henry VIII continued royal patronage of this company, and in 1515 he divided the players into two groups, one to perform at court and the other to perform on tour. He also began the practice of having his wives and children patronize playing companies bearing their names. ${ }^{4}$ The King's Players would have been gifted and versatile improvisers, but as a standing company they would also have mastered a standard repertoire of interludes to perform on command at court and to offer for performance on the road. Although the authors and auspices of many surviving plays from the earlier Tudor period remain mysterious, ${ }^{5}$ Henry VIII's company appears to have employed practices that would become fully developed repertorial strategies exploited later by the Queen's Men and other professional playing companies. As W.R. Streitberger points out, Henry VIII's 'creation of this company is one of the milestones in the development of the English theatre, for it permanently linked the royal company to professional playing. ${ }^{6}$

\section{Proto-Repertorial Practices on John Rastell's Stage}

Amidst the Henrician court's enthusiasm for innovations in drama and performance, ${ }^{7}$ John Rastell — playwright, lawyer, adventurer, and printer developed his talents as a professional producer of plays and spectacles. Rastell first undertook work with dramatic production while still living in his hometown of Coventry, ${ }^{8}$ then polished his skills at court, where gifted musicians, playwrights, and performers (including Rastell's son-in-law, John Hey$\operatorname{wood}^{9}$ ) were highly esteemed. The court certainly recognized and rewarded Rastell's production activities. He received praise for his work on the construction and decoration of the banqueting hall at the Field of the Cloth of Gold in 1520, and in 1522 he was commissioned to create an elaborate pageant along the procession route for Charles V's state visit; he did not disappoint. ${ }^{10}$

Around 1517 Rastell wrote the humanist interlude The Four Elementis; at the time, this play may have been performed at court or the inns of court, or both. ${ }^{11}$ In 1524 Rastell leased property fronting on Old Street in Finsbury where he built a house and erected London's first purpose-built stage for dramatic performances. Although it stands to reason that Rastell would produce 
his own play in his new venue, admittedly the only surviving records of Rastell's stage are lawsuits brought forward in 1530 and 1531 in which Rastell sued Henry Walton for loss of and damage to costumes Rastell had lent him. Walton, the builder of Rastell's stage and a play producer himself, countersued Rastell for nonpayment. ${ }^{12}$ Two of the men who gave testimony in support of Rastell were members of the King's Players: George Mayler and George Birch. ${ }^{13}$ Both Mayler and Birch had worn Rastell's costumes in performance, and Mayler claims to have had a part in sewing them. This overlap of court and public stage actors suggests possible repertorial overlap since the players would have brought their stock of plays with them from venue to venue. ${ }^{14}$ While the lawsuits indicate theatrical rivalries and resentments, the apparent layers of collaboration and exchange among these players and producers may also point to a lively theatrical network in 1520 s London.

David Kathman has termed Rastell's theatrical venture an example of 'proto-commercialism' in London theatrical practice. ${ }^{15}$ As a businessman, Rastell certainly imagined himself an innovator, and his stage was an admirably daring experiment in commercial theatre - even if his project did eventually collapse and end in lawsuits. ${ }^{16}$ Arguably, Rastell's theatrical practices were entirely 'proto': proto-public, proto-professional, and proto-repertorial in addition to their being proto-commercial. Rastell also conceived of his public theatre as a platform for disseminating the views of his humanist circle, members of which were especially fond of dialogue and dramatic debate. ${ }^{17}$ Joel Altman identifies a group of humanist plays associated with Rastell as 'plays of inquiry', ${ }^{18}$ which Altman treats as elite court drama, avoiding altogether the matter of Rastell's public stage. At first this approach seems sensible since we have no record of the plays performed on this first public stage. Yet an examination of Rastell's ideological and entrepreneurial motivations, his work as a printer, and his connections with performers and performance culture both inside and outside the court environment invites our speculative reconstruction of his theatre's dramatic repertory. In so doing, we might imagine that plays for Rastell's stage came from several sources: those plays Rastell wrote all or part of, plays Rastell printed post-performance, and plays written by Rastell's son-in-law John Heywood.

The Four Elementis remains the only play scholars attribute to Rastell with absolute certainty. The playbook, which Rastell printed around 1520, is not merely a literary production intended for readers. It also contains clues about performance conditions in the form of a headnote with instructions for cutting the text, and the time required to perform it, by up to half: 
yf the hole matter be playde, wyl conteyne the space of an hour and a halfe; but yf ye lyst ye may leve out much of the sad mater, as the messengers parte, and some of Naturys parte and some of Experyens parte, and yet the matter wyl depend convenyently, and than it wyll not be paste thre quarters of an hour of length. ${ }^{19}$

Rastell thus announces that he wrote The Four Elementis with a 'modular structure' in mind. ${ }^{20}$ Such a flexible construction not only permitted performance during different sorts of court or inns of court festivities, but also rendered the play easily adaptable for performance in other venues and for other audiences. Performance of this play at John Rastell's Finsbury stage is conceivable, even probable; references in the text to great hall performance could easily be removed for this purpose. The Four Elementis contains comic sections that would appeal to all audiences, whether or not some of the 'sad' (serious) humanist matter appeared in a performance. Uncut the play would have been most appropriate for educated audiences in royal or noble households and the inns of court. ${ }^{21}$ By means of the headnote, Rastell seeks to assert his control over dramaturgical decisions that could disrupt his text. He thus demonstrates his shrewd awareness that his play, once printed, might also be performed in a wide variety of settings beyond his immediate authorial reach.

Printing was one of John Rastell's more successful business ventures, and we may reasonably imagine that he printed plays with which he had some sort of involvement as a writer or producer, or both. As with later sixteenthcentury practice, printing of early and mid-Tudor plays mostly post-dates performance. ${ }^{22}$ Few plays from this period are extant in manuscript form. For the most part only plays that were printed have survived, but surely many more were performed but never documented in print. ${ }^{23}$ Manuscript part rolls appear to have been treated as disposable, and manuscript master copies seem mostly to have been discarded as well. Sometime between 1512 and 1516, Rastell printed Henry Medwall's Fulgens and Lucrece, the first printed playbook in England; no manuscript survives. Rastell may have seen this humanist comedy performed at court and perhaps came into possession of a manuscript through his kinship with Thomas More. ${ }^{24}$ In addition to The Four Elementis and Fulgens and Lucrece, Rastell printed Calisto and Melebea and commissioned Peter Treveris to print John Skelton's Magnyfycence. ${ }^{25}$ In the early 1530s, William Rastell took over his father's printing business and issued five plays by John Heywood, most of which had been written by the late 1520s. In all probability, each of the plays John Rastell printed in the 
mid-to-late 1520s had also been performed on his public stage, and several of the plays William Rastell printed in the 1530s appeared there as well. For John Rastell the production and the printing of these plays advanced his humanist program to 'reach and educate the widest possible audience'. ${ }^{26}$

\section{Gentylnes and Nobylyte: A Case Study in Collaboration}

Around 1525 John Rastell printed the comic humanist interlude Gentylnes and Nobylyte. ${ }^{27}$ This play and its printed playbook offer insight into the activities of John Rastell and his son-in-law John Heywood, while highlighting the forces that shaped theatrical repertory in this period, in particular performance venues, audience composition, and authorial collaboration. ${ }^{28}$ In Rastell's first printing of the play, which likely post-dates the play's first performances, two paratextual features of the playbook simultaneously illuminate and confuse authorial identity. These two features are the portrait of a lanky man on the frontispiece and the printer's colophon that appears on the last page. The frontispiece portrait bears the initials 'I H' for 'John Heywood'; the printer's colophon reads 'Iōhes rastell me fieri fecit' or 'John Rastell caused me to be made'. ${ }^{29}$ As Randall McLeod points out, 'it is very common that the first and last pages of printed books to talk each other'. ${ }^{30}$ This is certainly the case in Rastell's printing of Gentylnes and Nobylyte, but precisely what the frontispiece is saying to the colophon remains uncertain. Attribution of Gentylnes and Nobylyte has tended to rely heavily upon the colophon's language while avoiding the implications of authorship embedded in Heywood's frontispiece portrait. ${ }^{31}$ But taken together the portrait and colophon imply each man's participation in the larger project of writing, producing, and performing Gentylnes and Nobylyte.

Like Fulgens and Lucres, Gentylnes and Nobylyte encapsulates the question of whether the qualities of gentleness and nobility are inherited or inherent one of the More circle's most cherished preoccupations. But the debate play's generic insistence on a dispute diffuses the play's ideology among its three dramatic characters - the Knight, the Merchant, and the Plowman — who conduct the debate from their respective positions in the socio-economic hierarchy. The Philosopher, a judge figure, finally delivers an epilogue that announces a lopsided compromise allowing for the continuing dominance of the ruling class while exhorting that group to use its wealth to advance the common good. Axton and Cameron both assert that John Rastell wrote the Philosopher's epilogue, a humanist discourse that concludes just above 
Rastell's me fieri fecit colophon. ${ }^{32}$ Yet the final stanza of this speech alone contains an array of references to potential contributors to this play:

And though that I my selfe now percase

Thus myn opynyon have publysshed

Or any of my felowes here in this place

In any poynt here have us abused

We beseche you to holde us excused

And so the auctor herof requyreth you all

And thus I commyt you to God eternall.

AMEN.

In the first line, the Philosopher-figure refers to 'I my selfe' who has ventured to make his opinion public; in the fourth and fifth lines the Philosopher issues the players' conventional apologia; then in the sixth line the Philosopher indicates that 'the auctor' of the play seeks to be excused for any offence to the audience. In line seven, the 'I my selfe' of the first line re-emerges and commits the audience to God in the same way ('thus') as the author. So we have first-person self-references to 'I' the Philosopher and 'we' the players as well as a third-person reference to the 'auctor'.

David Bevington cautions that on the basis of the play's topicality alone reliable attribution of Gentylnes is not possible, ${ }^{33}$ but another aspect of the Philosopher's speech is strongly suggestive of Rastell's authorship: its versification. The speech is written in rhyme royal and the rest of the play is in rhymed couplets, John Heywood's preferred verse. ${ }^{34}$ In Heywood's plays, the shaky metrical feet and doggerel verse set incongruously into the formal frame of debate contribute to the comedy. ${ }^{35}$ Rastell, however, seeks to represent himself and his humanist ideas more seriously by means of a speech in a more sophisticated verse form. Rastell also employs rhyme royal on at least two other occasions: in his play The Four Elementis and in his encomiastic prologue to Chaucer's Parliament of Foules, which he printed ca $1525 .{ }^{36}$

As Anne Middleton has noted in a different context, the 'indeterminacies' that emerge from 'ambiguous "internal evidence" of authorship appear 'capable of resolution only by appeal to information ... outside the text'. 37 In the case of Gentylnes and Nobylyte, this information is paratextual. The printer having the playbook announce its own maker may at first seem a fairly straightforward way for him to claim credit for his activities, but the language of the colophon obscures the complexity of Rastell's role. Early twentieth-century critics debated the colophon's meaning and settled upon 
indications of printership while continuing to debate authorship. ${ }^{38}$ By the century's end Rastell's bibliographer E.J. Devereux maintained that the play's authorship could not be attributed on the basis of the printer's colophon, then erroneously claimed that the colophon represented a 'playful variation' on the writ of fieri facias, a legal instrument employed to seize the property of debtors. ${ }^{39}$ The assumption undergirding these readings of the colophon is that language is primarily 'intermediary and instrumental', lending itself to transmitting its assigned message in the appropriate form - in this case an announcement. ${ }^{40}$ But of what? Rastell's colophon remains a source of confusion, an indeterminate verbal performance that fails as an instrumental sign unless Rastell intended to signal ambiguity.

The Gentylnes and Nobylyte colophon invites comparison with other Rastell printer's marks and with the wider practices of self-referentiality among early printers in England. Viewed among comparanda, Rastell's colophon stands in a slippery relationship both to the frontispiece portrait of Heywood and to the play text itself. The colophon suggests the wide range of roles Rastell is likely to have played in the production of the play on stage, the play text, and the printed playbook during this transitional period from manuscript to print when the relations of authors and printers were still undefined. Indeed, bearing in mind the elasticity of the term 'maker' and Rastell's vision of himself as a poet and playwright, Rastell's making of Gentylnes and Nobylyte may indicate more complex activities than those connected with other playbooks he printed. For instance, Rastell's colophon to his ca 1525 printing of the play Calisto and Melebea reads 'Iohes Rastell me imprimi fecit' - 'John Rastell caused me to be printed'. 41 Problematically, neither of these plays explicitly contains an author's name; instead, a 'maker's' name is provided for one and a printer's name for the other, and in each case that name is John Rastell's. Whether Rastell is the author or printer or both, he effectively suppresses authorial identity for both plays. He performs his role as printer in a way that suggests his higher regard for the playprinter's application of the new technology than for the playwright's creative efforts. It is conceivable that in the early days of playbook printing in England play-writers, play-producers, and play-printers all imagined themselves as playwrights - the makers of plays.

The evident participation of both Rastell and Heywood in the writing of Gentylnes and Nobylyte combines with their close familial relations, involvement with entertainments at court, and complementary theatrical interests to point to the high likelihood of their having collaborated from the late 
1510s to the early 1530 s. ${ }^{42}$ The further possibility that Rastell commissioned Heywood to write plays for his public stage must also be considered. After all, both fieri and fecit are forms of the verb facio, which means 'to make', and the phrase me fieri fecit simultaneously expresses active and passive functions someone making something and something being caused, or commissioned, to be made. The Gentylnes and Nobylyte frontispiece portrait bearing the initials 'I H' certainly implicates John Heywood as some sort of collaborator in Rastell's dramatic activities. Authorship attribution debates have largely neglected this image, although the representation is unquestionably of Heywood. This woodcut portrait is virtually identical to a later portrait of Heywood that appears, initials 'I H' and all, in Thomas Powell's 1556 printing of Heywood's The Spidere and the Flie. Powell used the same woodcut, but added filling ornament and, as authenticating details, a few facial wrinkles and a sagging chin to suggest Heywood's more advanced age. ${ }^{43}$

In Gentylnes and Nobylyte Rastell gives Heywood top billing by means of the full-page, full-length portrait at the front of the playbook. The nature of the portrait and its placement are obviously important; yet we cannot determine precisely what they signify. Does this portrait represent the author or the performing artist, or both? As a performer both at court and on Rastell's stage, spectators would have known Heywood and may even have constituted a coterie of fans. In this case, Heywood's portrait would serve not merely as an announcement of his creative contribution, but also as a commercial advertisement designed by the enterprising Rastell to attract playbook buyers from among theatregoers.

Heywood's ambiguous frontispiece portrait is peculiar, but Rastell's colophon is part of a long and overlooked tradition of attributive practice that predates print and includes many earlier uses of me fieri fecit in inscriptions on buildings and within manuscripts. In its medieval usage, the 'so-andso me fieri fecit' inscription means 'so-and-so commissioned me' and does not imply that the commissioner was also the actual 'maker' of the manuscript book or the building. In manuscript culture the phrase refers not to the scribes and artisans who made the books, but instead to the wealthy patrons who commissioned the costly manuscripts for their own use. Among other places, ${ }^{44}$ this usage occurs above the famous image from the Luttrell Psalter in which Sir Geoffrey Luttrell appears with his horse, his wife Agnes de Sutton, and his daughter-in-law Beatrice le Scrope. Frequently omitted from reproductions of this aristocratic family scene is its inscription which reads 'Dominus Galfridus Louterel me fieri fecit' - 'Sir Geoffrey Luttrell 
commissioned me. ${ }^{45}$ This book does not inform the reader or viewer of the names of the single scribe or the five artisans thought to have contributed their talents to creating the manuscript. Instead, the book declares the name of its wealthy patron and gives him all the credit.

With the advent of print, 'me fieri fecit' accumulated meaning as it began to refer to the activities of the printers, but this phrase appears chiefly when a printer's activities included something more than just printing. This semantic adaptation apparently derived from the conflation of the traditional use of 'me fieri fecit' to credit aristocratic patrons with the desire of the people performing the actual labour of book production to make themselves and their skills known to potential customers. In early English printing only William Caxton and John Rastell employed this colophon. Caxton used it a total of six times, all between 1485 and 1491, including for his printing of Malory's Morte Darthur. In addition to Caxton's work as a printer, on several bookproduction projects he was also writer, translator, compiler, editor, or some combination of these roles.

John Rastell employed me fieri fecit just twice, and both instances occur in the mid-1520s. Like Caxton, Rastell was also a writer, editor, translator, compiler, and printer. Problematically, in one of Rastell's two uses of the phrase he attached this colophon to a book that he did not actually print Lucian's Necromantia, which Thomas More and John Rastell collaboratively translated and Rastell commissioned Peter Treveris to print. ${ }^{46}$ This situation strongly suggests that Rastell entertained a capacious understanding of ' $m e$ fierifecit' possibly derived from his knowledge of Caxton's range of activities. Rastell seems also to have possessed a similarly broad understanding of the meaning of 'me imprimi fecit'. Although Rastell had used this phrase to indicate his actual printing of Calisto and Melebea, in the case of the Abbreviation of Statutes, which Rastell edited, he employed 'me imprimi fecit' to indicate that he had caused that book to be printed when he commissioned Peter Treveris to print it. ${ }^{47}$

John Rastell's practices as a printer thus provide tantalizing clues to his theatrical circle's complex repertory-building activities, including production, performance, and the likelihood of collaborative authorship of plays. As Anne Middleton observes, the authorship question is one of 'boundaries ... what is "proper" to the authorial enterprise as such, and what it has in common with other cultural work'. ${ }^{48}$ For Gentylnes and Nobylyte, Rastell seemingly engaged in a range of cultural work, which involved writing and possibly even performing the Philosopher's speech, as well as producing and 
printing the entire play. The indeterminacy of John Rastell's self-attribution simultaneously establishes and sabotages the boundaries among all these theatrical tasks and encourages us to imagine that Rastell and Heywood may have set in motion some of the collaborative practices we now recognize as typical of repertory development for London's commercial stages of the later sixteenth century.

Earlier Tudor drama deserves the attention of repertory studies and should be interrogated in its own right, not merely as the forerunner of Elizabethanera theatrical practices. The Henrician period witnessed the first professional company and secular theatre in England, and fresh study of its collaborative networks hold the potential to shine a light on the innovative repertory practices of performers, playwrights, and companies operating at this transitional moment in noble households, at the court, on tour, and on London's first public stage.

\section{Notes}

I would like to thank Erin Kelly, Paul Olson, Abraham Stoll, John Watson, Yasmine Hachimi, Stefan Vander Elst, Helen Ostovich, and the anonymous reader for Early Theatre for their insightful critiques of this essay.

1 Among indispensible works in the field of repertory studies are the following: Roslyn Knutson, 'Influence of the Repertory System on the Revival and Revision of The Spanish Tragedy and Doctor Faustus', English Literary Renaissance 18.2 (1988), 25774, The Repertory of Shakespeare's Company (Fayetteville, 1991), 'The Repertory', John D. Cox and David Scott Kasten (eds), A New History of Early English Drama (New York, 1997), 461-79, and Playing Companies and Commerce in Shakespeare's Time (Cambridge, 2001); Scott McMillin and Sally-Beth MacLean, The Queen's Men and their Plays (Cambridge, 1998); Andrew Gurr, Shakespeare's Opposites: The Admiral's Company 1594-1625 (Cambridge, 2009); Helen Ostovich, Holger Syme, and Andrew Griffin (eds), Locating the Queen's Men (Burlington VT, 2009); and Lucy Munro, 'Early Modern Drama and the Repertory Approach', Research Opportunities in Renaissance Drama 42 (2003), 1-33..

2 Munro, 'Early Modern Drama', 3.

3 On collaboration in the development of repertory for the Elizabethan and Stuart stages, see Gerald Bentley, 'Collaboration', in The Profession of Dramatist in Shakespeare's Time, 1590-1642 (Princeton, 1971), 197-234; and Jeffrey Masten, 
'Playwriting: Authorship and Collaboration', A New History of Early English Drama, 357-82.

4 W.R. Streitberger, 'Adult Playing Companies to 1583', Richard Dutton (ed.), The Oxford Handbook of Early Modern Theatre (Oxford, 2009), 20-1, DOI: http:// dx.doi.org/10.1093/oxfordhb/9780199697861.013.0002 and see James Forse's article in this issue on the question of naming companies, 61-92.

5 For the surviving plays and fragments, see Darryl Grantley, English Dramatic Interludes, 1300-1550 (Cambridge, 2004).

6 Streitberger, 'Adult Playing Companies', 21.

7 See especially Greg Walker, Plays of Persuasion: Drama and Politics at the Court of Henry VIII (Cambridge, 1991); for a revisionist perspective on Henry VIII's attitude toward drama, see Jeanne McCarthy, 'The Emergence of Henrician Drama "in the Kinges absens", English Literary Renaissance 39.2 (2009), 231-66, DOI: http:// dx.doi.org/10.1111/j.1475-6757.2009.01046.x

8 The Corpus Christi Guild Account Book records between 1491 and 1513 seven payments to and from John Rastell. See R.W. Ingram (ed.), REED: Coventry (Manchester, 1981), 75-109.

9 John Heywood first appeared in Henry VIII's household payment records in 1519; Heywood married Rastell's daughter Joan (Thomas More's niece) ca 1523.

10 On Rastell's court production activities, see Sydney Anglo, Spectacle, Pageantry, and Early Tudor Policy, 2nd ed. (Oxford, 1997), 164-7, 196-7, and 262-5 as well as Albert Geritz and Amos Laine, John Rastell (Boston, 1983), 14-15. In 1527 Rastell organized the entertainment for the French ambassadors at Greenwich (Geritz and Laine, 18; Anglo, 212-25). Rastell designed an elaborate mechanical set for the pageant and Thomas More delivered 'an eloquent oration' in Latin during the festivities; see Edward Hall, The Union of the Two Noble and Illuste Famelies of Lancastre and Yorke (London, [1548] 1809), 637.

11 Rastell printed his play ca 1520: John Rastell, The Four Elementis (London, ca 1520; STC 20722) EEBO.

12 David Kathman, 'The Rise of Commercial Playing in 1540s London', Early Theatre 12.1 (2009), 15-38 notes that 'Walton and his ffelowes' hired the St. Botolph without Aldergate churchyard for play performance (16-17). See Mary C. Erler (ed.), REED: Ecclesiastical London (Toronto, 2008), 74-85. Janette Dillon, 'John Rastell v. Henry Walton', Leeds Studies in English 28 (1997), 57-75 notes that she has been 'unable to trace any judgement in the case' (73n1). See also A.W. Reed, Early Tudor Drama: Medwall, the Rastells, Heywood, and the More Circle (New York, [1926] 1969), 230-3. 
13 For the testimony, see REED: Ecclesiastical London (Toronto, 2008), 74-85 and Janette Dillon, 'John Rastell's Stage', Medieval English Theatre 18 (1996), 15-45, esp. 23.

14 Janette Dillon notes that it is possible that the 'Finsbury stage was a collaborative venture between Rastell and Walton'; 'John Rastell's Stage', 17.

15 David Kathman, 'The Rise of Commercial Playing', 16-17.

16 As did several other Rastell ventures. The most notable failure was Rastell's attempted voyage to America in March 1517, at the start of which the crew mutinied, left Rastell stranded in Ireland, and took the ship to Bordeaux where they sold its contents; see Geritz and Laine, John Rastell, 14-15.

17 This circle included Rastell's brother-in-law and fellow lawyer Thomas More. For Rastell as an independent dissident voice, see Peter C. Herman, 'Rastell's Pastyme of People: Monarchy and the Law in Early Modern Historiography', Journal of Medieval and Early Modern Studies 30.2 (2000), 275-308, DOI: http://dx.doi .org/10.1215/10829636-30-2-275.

18 Joel Altman, The Tudor Play of Mind (Berkeley, 1978), 26-7; Altman includes plays by Rastell, Medwall, and Heywood in this category.

19 Rastell, The Four Elementis, A1r.

20 David Klausner develops this useful concept in 'The Modular Structure of Wisdom', David Klausner and Karen Marsalek (eds), 'Bring Furth the Pagants': Essays in Early English Drama Presented to Alexandra Johnston (Toronto, 2007), 181-96.

21 Suggestively, Rastell was himself an utter barrister of Middle Temple.

22 Shakespeare's Troilus and Cressida may be an exception. In the later sixteenth century, playwrights and playing companies would not have been eager to see their plays go into print while they were still being performed. As a printer, however, Rastell had a direct financial interest in seeing his own and his circle's plays in print.

23 Curiously, John Heywood's Witty and Witless is one such (BL Harleian Ms 367).

24 Henry Medwall, Fulgens and Lucres (London, ca 1512-16; stC 17778). More was a great fan of drama and would have known Medwall's play from its earliest performances in the household of Archbishop, later Cardinal, John Morton, where both were in residence in the 1490s; see William Roper, The Lyfe of Sir Thomas More, Knyghte ([London, 1556] Paris, 1626; sтc 21316) EEBO, A1v.

25 Unattributed, Calisto and Melebea (London, ca 1525; sтс 20721); John Skelton, Magnyfycence (London, 1530; sTC 22607).

26 Dillon, 'John Rastell's Stage', 31.

27 Of Gentylnes and Nobylyte (London, c 1525-7; sтc 20723).

28 The play's social and humanist themes may have been most appealing to a court audience: Daniel Wakelin 'Gentleness and Nobility, John Rastell, c 1525-27', The 
Oxford Handbook of Tudor Drama (Oxford, 2012), 192-206, DOI: http://dx.doi .org/10.1093/oxfordhb/9780199566471.013.0012; Richard Axton, Three Rastell Plays (Cambridge, 1979) notes that the play's 'satirical jibes against knights and merchants would be most appreciated by an audience from those classes' (21).

29 Of Gentylnes and Nobylyte. All references to the play text are to Richard Axton (ed.), Gentylnes and Nobylyte, in Three Rastell Plays, 98-124.

30 Randall McLeod. 'The Librarynth' Plenary Lecture, Pacific Northwest Renaissance Society conference on Reading, Writing, Printing, and Performance. University of Victoria (Canada), 22 October 2010.

31 Most recently, Wakelin, 'Gentleness and Nobility'. Earlier treatments similarly overlook the Heywood frontispiece while variously attributing the work to Rastell (on the basis of the colophon) or to Heywood (on the basis of the language and the Chaucerian tropes) or to both. See H.N. Hillebrand, 'On the Authorship of the Interludes Attributed to John Heywood', Modern Philology 13.5 (1915), 267-80, DOI: http://dx.doi.org/10.1086/387008; C.F. Tucker Brooke, 'Gentleness and Nobility: The Authorship and Source'. Modern Language Review 6.4 (1911), 458-61, DOI: http://dx.doi.org/10.2307/3713280; Esther C. Dunn, 'John Rastell and Gentleness and Nobility', Modern Language Review 12.3 (1917), 266-78, DOI: http://dx.doi .org/10.2307/3714091; and C.R. Baskervill, 'John Rastell's Dramatic Activities', Modern Philology 13.9 (1916) 557-60, DOI: http://dx.doi.org/10.1086/387023. David Bevington, Tudor Drama and Politics (Cambridge, 1968) notes that 'joint authorship is by no means out of the question' (76); see also Rachel Greenberg, 'From Subject to Earthly Matter: The Plowman's Argument in Gentleness and Nobility' Early Theatre 15.2 (2012), 13-42. At this writing, I am conducting a digital author attribution project that analyzes Gentylnes and Nobylyte and other plays of questionable authorship from the 1520s. I expect to have results to share in mid-2015.

32 Axton (ed.), Three Rastell Plays, 21, 26; Kenneth W. Cameron, Authorship and Sources of 'Gentleness and Nobility': A Study in Early Tudor Drama (Raleigh, 1941), 59-63.

33 Bevington, Tudor Drama and Politics, 76.

34 J.E. Bernard, The Prosody of the Tudor Interlude (New Haven, 1939), 54 attributes Gentylnes and Nobylyte to Heywood and in so doing asserts that the Philosopher's speech is Heywood's failed attempt at rhyme royal. For a terse critique of the poetic skill of Heywood and other interlude writers, see Derek Pearsall, Old and Middle English Poetry (London, 1977), 257.

35 The pattern also holds in Gentylnes and Nobylyte, which oppugns attribution of the play's debates to Rastell (see Wakelin, 'Gentleness and Nobility', 196). 
36 Geoffrey Chaucer, Parlyament of Fowles (London, ca 1525; sTC 5091.5). Rastell printed Chaucer's poem and Gentylnes and Nobylyte at about the same time, and each work stands in the tradition of four-estate debate; see Paul Olson, 'The Parlement of Foules: Aristotle's Politics and the Foundations of Human Society', Studies in the Age of Chaucer 2 (1980), 53-69.

37 For acute and instructive analysis of the underlying dilemmas obtaining to questions of authorship see Anne Middleton, 'William Langland's "Kynde Name"', Lee Patterson (ed.), Literary Practice and Social Change in Britain, 1380-1530 (Berkeley, 1990), 15-82, esp. 19.

38 For instance, Baskervill, 'Dramatic Activities'; Dunn, 'John Rastell'; Tucker Brooke, 'Gentleness and Nobility'; and Hillebrand, 'Authorship'.

39 E.J. Devereux, A Bibliography of John Rastell (Montreal, 1999), 122. Devereux misinterprets Rastell's colophon as an allusion to the printer's ongoing money troubles.

40 Émile Benveniste, 'Subjectivity in Language', Problems in General Lingustics. Trans. M.E. Meek (Miami, 1971), 223.

41 Calisto and Melebea (London, ca 1525; stc 20721); Devereux, A Bibliography, 123.

42 A familial rupture occurred after Rastell converted to radical Protestantism in 1533; his son-in-law Heywood remained Catholic (as did his brother-in-law More). Heywood's court playwriting seems to have tapered off amidst the atmosphere of growing tyranny in the early 1530s; around this time William Rastell took over his father's printing business and printed several of Heywood's plays.

43 John Heywood, The Spidere and the Flie (London, 1556; sTC 13308); for a discussion of other early printers' repurposing of woodcuts, see Martha Driver, The Image in Print: Book Illustration in Late Medieval England and its Sources (London, 2004), 33-77.

44 The inscription also appears on the front fly-leaf of the mid-fifteenth-century Culross Psalter, where Richard Marshall, the abbot of Culross, is credited with commissioning that manuscript book; Advocates ms 18.8.11, National Library of Scotland. The gold inscription reads 'Me fieri fecit Ricardus Marchel quoda abbas de Culeros que ds salvet hic et in evum'. See also W.K. Dickson, 'Notes on the Culross Psalter', Proceedings of the Society of Antiquaries of Scotland 5th series, 51.2 (1917), 208-13.

45 Luttrell Psalter, BL Add. ms 42130 (c 1320-40), f. 202v.

46 Lucian, Necromantia, trans. Thomas More and John Rastell (London, ca 1523-26; STC 16895); Devereux, A Bibliography, 121.

47 John Rastell (ed.), Abbreviation of Statutes (London, 1528; stc 9620); Devereux, A Bibliography, 152-5.

48 Middleton, 'Langland's "Kynde Name”, 18. 